\title{
Effects of the dietary energy source on meat quality and eating quality attributes and fatty acid profile of Simmental bulls
}

\author{
Ahmed S. SAMI ${ }^{\text {a* }}$, Josef KOEGEL ${ }^{\mathrm{b}}$, Hans EICHINGER ${ }^{\mathrm{c}}$, \\ Peter FREUDENREICH ${ }^{\mathrm{d}}$, Frieder J. SCHWARZ ${ }^{\text {a** }}$ \\ ${ }^{\text {a }}$ Section of Animal Nutrition, Department of Animal Science, Technical University of Munich, \\ Hochfeldweg 6, 85350 Freising-Weihenstephan, Germany \\ ${ }^{\mathrm{b}}$ Animal Breeding Institute, Bavarian State Research Centre of Agriculture, 85586 Grub, Germany \\ ${ }^{\mathrm{c}}$ Bioanalytical Laboratory Weihenstephan, Technical University of Munich, \\ 85350 Freising-Weihenstephan, Germany \\ ${ }^{\mathrm{d}}$ Federal Research Centre for Nutrition and Food, E.-C. Baumann-Str. 20, 95326 Kulmbach, Germany
}

(Received 13 June 2005 - Accepted 13 February 2006)

\begin{abstract}
Seventy-two Simmental bulls, weighing at the beginning of the experiment $408 \pm 24 \mathrm{~kg}$, were fed fibrous or starch diets to a final weight of $622 \pm 34 \mathrm{~kg}$. The animals were divided into three groups fed with the following: grass silage plus sugar beet pulp (GSS, $\mathrm{n}=18$ ) as a predominantly fibrous diet, maize silage plus wheat (MSW, $n=27$ ) and maize silage plus corn (MSC, $n=27$ ) as predominantly starch diets with different ruminal degradabilities of the starch. The dietary source of energy had no significant effects on the following meat characteristics: $\mathrm{pH}$, colour, weight losses at ageing and grilling, grilling time and shear force values. These meat quality traits were also not affected by the dietary source of starch, rapid degradable (MSW) or slow degradable (MSC). In loin muscle steaks, sensory evaluation revealed no significant differences in tenderness and juiciness among the three groups. The steaks of the grass silage fed group (GSS) were rated lower for flavour than the steaks from the maize silage fed groups (MSW, MSC), with the difference between GSS and MSC being significant. The MSC group also had the highest intramuscular fat content with $1.96 \%(P<0.05)$. Feeding the GSS diet significantly increased the saturated fatty acids in the intramuscular and kidney fat compared to the MSW and MSC diets. Also, most polyunsaturated fatty acids especially $n-3$ fatty acids were increased by feeding the GSS diet. The MSC diet significantly reduced the PUFA in the intramuscular and kidney fat compared to the GSS diet. MUFA content was significantly higher when feeding starchy diets.
\end{abstract}

energy / meat quality / fatty acid profile / Simmental bulls

\footnotetext{
* Current address: Animal Production Department, Faculty of Agriculture, Cairo University, 12613, Giza, Egypt, e-mail: assami70@yahoo.com

** Corresponding author: schwarzf@wzw.tum.de
} 
Résumé - Effets de la source d'énergie de la ration sur la qualité de la viande et ses caractéristiques gustatives et qualitatives, et le profil des acides gras chez les taurillons Simmental. Soixante-douze taurillons Simmental, pesant au début de l'expérience $408 \pm 24 \mathrm{~kg}$, ont été alimentés avec des régimes à base de fibres ou d'amidon jusqu'à un poids final de $622 \pm 34 \mathrm{~kg}$. Les animaux ont été divisés en trois groupes alimentés soit avec de l'ensilage d'herbe et de la pulpe de betterave (GSS, $\mathrm{n}=18$ ) comme régime riche en fibres, soit avec de l'ensilage de maïs et du blé (MSW, $\mathrm{n}=27$ ) ou de l'ensilage de maïs et du maïs (MSC, $\mathrm{n}=27$ ) comme régimes riches en amidon avec des dégradabilités ruminales différentes. La source d'énergie de la ration n'a eu aucun effet significatif sur les caractéristiques suivantes pour la viande : $\mathrm{pH}$, couleur, pertes de poids après maturation et après cuisson, temps de cuisson, et force de cisaillement. De même, la source d'amidon du régime, qu'il soit rapidement dégradable (MSW) ou lentement dégradable (MSC), n'a eu aucun effet sur ces paramètres. Pour les filets, l'évaluation sensorielle n'a indiqué aucune différence significative de tendreté et de jutosité de la viande entre les trois groupes. Les filets du groupe nourris à l'ensilage d'herbe (GSS) ont eu une flaveur moindre par rapport aux filets des groupes alimentés avec l'ensilage de maïs (MSW, MSC), avec une différence significative entre les groupes GSS et MSC. Le groupe MSC a également eu la teneur en lipides intramusculaires la plus élevée avec $1,96 \%(P<0,05)$. Le régime GSS a augmenté de manière significative les acides gras saturés dans le gras intramusculaire et périrénal comparativement aux régimes MSW et MSC. En outre, la plupart des acides gras polyinsaturés (PUFA), en particulier les acides gras n-3, ont été augmentés avec le régime GSS. Le régime MSC a réduit de manière significative les PUFA dans les lipides intramusculaires et périrénaux comparé au régime GSS. Le contenu de MUFA était sensiblement plus élevé avec les régimes riches en amidon.

énergie / qualité de la viande / profil des acides gras / taurillons Simmental

\section{INTRODUCTION}

Any improvement of meat production by breeding and/or nutritional means should take into consideration the composition and palatability of the meat. Many factors have an impact on ruminant meat quality; they can generally be divided into two categories: somatic factors (e.g. breed, age, sex) and environmental factors (e.g. diet, climate, slaughtering procedures). Feed costs form the major proportion of all variable costs in beef production systems, but the reduction of feed costs should not be accompanied by a reduction of the meat quality. However, the specific effects of the dietary constituents on meat quality are not difficult to identify. The feeding regime itself will influence the animal growth rate and will indirectly affect the meat characteristics. These characteristics may also be changed due to the dietary components and their intrinsic properties [18]. Maximum energy intake can be achieved by maximising dry matter intake and by increasing the energy concentration of the diet by adding fat or adding energy rich concentrates. Under practical conditions this will be achieved most frequently by feeding more cereal grain starch [19].

Bacteria fermenting starch produce a higher proportion of propionic acid (35 to 45 moles per 100 moles VFA) than bacteria fermenting cellulose or hemicellulose (15 to 20 moles per 100 moles VFA) [16]. The production of propionic acid is more advantageous, because propionic acid serves as a hydrogen sink and is utilised more efficiently than acetic acid. Therefore, high starch diets may be more favourable in fattening rations compared to high fibre diets in cattle. High starch diets usually increase the production costs and other sources of energy would be more acceptable provided that there are no adverse effects on the meat quality. Therefore, the objective of this study was to compare the effects of a high fibrous diet with the effects of two starchy diets on meat quality traits, eating quality attributes and fatty acid profiles of Simmental bulls. 
Table I. Metabolisable energy, crude protein, starch and fibre contents of the experimental diets.

\begin{tabular}{lccc}
\hline Ingredient \% & GSS $^{1}$ & MSW & MSC \\
\hline Metabolisable energy & $10.6 \pm 0.20$ & $11.7 \pm 0.09$ & $11.7 \pm 0.09$ \\
(MJ $\cdot \mathrm{kg}^{-1}$ DM) & & & \\
Crude protein (\% in DM) & $15.1 \pm 0.53$ & $13.7 \pm 1.36$ & $13.0 \pm 1.18$ \\
Crude fat (\% in DM) & $2.60 \pm 0.35$ & $2.62 \pm 0.30$ & $3.09 \pm 0.33$ \\
Starch (\% in DM) & $6.8 \pm 1.68$ & $38.5 \pm 3.35$ & $38.1 \pm 2.81$ \\
Crude fibre (\% in DM) & $21.0 \pm 1.81$ & $14.8 \pm 1.29$ & $14.2 \pm 1.32$ \\
NDF (\% in DM) & $48.1 \pm 3.89$ & $33.4 \pm 2.60$ & $33.2 \pm 2.32$ \\
ADF (\% in DM) & $28.1 \pm 2.13$ & $18.0 \pm 1.72$ & $17.5 \pm 1.52$ \\
\hline
\end{tabular}

${ }^{1}$ GSS: Grass Silage and Sugar beet pulp + minerals; MSW: Maize Silage and Wheat + soyabean meal + minerals; MSC: Maize Silage and Corn + soyabean meal + minerals.

\section{MATERIALS AND METHODS}

\subsection{Experimental design}

Seventy-two Simmental bulls, 11 months old, and initially weighing $408 \pm$ $24 \mathrm{~kg}$, were randomly assigned to three groups differing in their dietary energy source. The experiment was performed at the agricultural experimental station, in Hirschau, of the Technical University of Munich, Freising-Weihenstephan, Germany. The roughage to concentrate ratio was $65: 35$ on a dry matter basis (DM). A high fibre diet (GSS, $\mathrm{n}=18$ ) consisted of grass silage $(46.3 \% \mathrm{DM}$, 9.99 $\mathrm{ME} \mathrm{MJ} \cdot \mathrm{kg}^{-1} \mathrm{DM}$ and $16.7 \%$ crude protein) and concentrates from sugar beet pulp (97.1\%) and a mixture of minerals $(2.9 \%)$. The other two diets were high in starch based on maize silage $(38.7 \%$

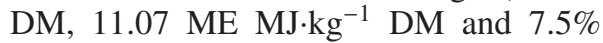
crude protein) and included concentrate from wheat $(51 \%)(\mathrm{MSW}, \mathrm{n}=27)$ or corn $(51 \%)$ (MSC, $\mathrm{n}=27)$ plus soybean meal $(45 \%)$ and a mixture of minerals $(4 \%)$. These three diets were fed as total mixed rations for each bull. The chemical composition of the three diets is given in Table I. During the experiment, two animals (one from MSW and GSS group) were excluded from the study due to health problems. Along the whole experiment, samples from the three diets were stored at $-20{ }^{\circ} \mathrm{C}$ for later fatty acid analysis. During the 157 day feeding period, individual daily feed intakes were recorded daily and bulls were weighed every $14 \mathrm{~d}$. Slaughtering took place at a mean final weight of $613 \mathrm{~kg}, 622 \mathrm{~kg}$ and $630 \mathrm{~kg}$ for GSS, MSW and MSC, respectively. The average age of the bulls was 16 months at slaughtering with no difference between the groups. The average daily gains were 1272,1358 and $1428 \mathrm{~g} \cdot \mathrm{d}^{-1}$ and the means for energy intake were 99.4, 103.9 and 103.6 MJ ME. $\mathrm{d}^{-1}$ for the GSS, MSW and MSC groups, respectively. Unlike energy intake, the average daily feed intake tended to be higher for GSS, $9.35 \mathrm{~kg}$ DM in comparison to 8.85 and $8.86 \mathrm{~kg} \mathrm{DM}$ for MSW and MSC, respectively.

\subsection{Slaughter procedure}

The bulls were fasted $18 \mathrm{~h}$ before slaughtering at a commercial abattoir. The carcasses were trimmed according to the EU legislation. The hot carcass weights for GSS, MSW and MSC groups were 340, 348, $356 \mathrm{~kg}$, respectively. The average dressing percentage was $55.5 \%$, $56.0 \%$ and $56.4 \%$ for GSS, MSW and 
MSC, respectively. Carcasses were split and cooled for $24 \mathrm{~h}$ at $4{ }^{\circ} \mathrm{C}$. The best ribs (9 to 11th) were removed from the left side of the carcasses and kept at $+4{ }^{\circ} \mathrm{C}$ during the transport to the Bavarian Institute for Animal Breeding, Grub. All meat samples were stored at $+4{ }^{\circ} \mathrm{C}$ for further meat quality measurements and sensory evaluation. Samples from the longissimus dorsi (LD) muscle and kidney fat were stored at $-20{ }^{\circ} \mathrm{C}$ for fatty acid analysis.

\subsection{Meat quality and sensory evaluation}

Meat $\mathrm{pH}$ value was measured in the LD muscle $48 \mathrm{~h}$ after slaughtering (pH-Meter Type Portamess, Knick, Berlin). The Minolta reflexion photometer (Minolta Europe $\mathrm{GmbH}$, Bremen, Germany) was used to measure meat colour ( $\mathrm{L}=$ lightness, $+\mathrm{a}^{*}=$ redness and $+\mathrm{b}^{*}=$ yellowness). Measurements of colour values were carried out at five spots of the LD muscle. The LD muscles were cut into three steaks at the height of the 9,10 and 11th rib. Each LD steak of the 9th rib was trimmed to remove residual adipose tissue and connective tissue for subsequent blending. One half part of the homogenised meat was vacuum packed and stored at $-20{ }^{\circ} \mathrm{C}$ for further fatty acid analysis. From the other part, direct measures of the intramuscular fat were performed using the near infrared reflectance method (NIR Systems 6500, FOSS Electric A/S, Denmark). The 10th rib steaks ( $3 \mathrm{~cm}$ thickness) were used for the determination of shear force values, ageing and grilling loss percentages. Each of these steaks was weighed, vacuum packaged and aged at $+2{ }^{\circ} \mathrm{C}$ for $13 \mathrm{~d}$. The steaks were weighed again and the ageing loss percentage was calculated. Subsequently, the steaks were heated until a core temperature of $65{ }^{\circ} \mathrm{C}$, grilling time was recorded, and the grilled samples were cooled to room temperature and weighed again to calculate the grilling loss percentage. Shear force was measured in the grilled steaks (INSTRON 5564, High Wycombe, UK). Cylindrical core samples were cut rectangular to the direction of the fibres. The steaks of the 11 th rib were vacuum packaged and stored at $-20{ }^{\circ} \mathrm{C}$. These steaks were used for sensory tests at the German Federal Research Centre for Nutrition and Food, Kulmbach. Taste panel ratings were carried out by six selected and calibrated, trained panelists. The LD steaks (2.5-cm thick) were grilled until a $70{ }^{\circ} \mathrm{C}$ core temperature. A 6-point scale was used to evaluate meat tenderness (1: tough and 6: very tender), juiciness (1: dry and 6: juicy) and flavour (1: weak and 6: strong).

\subsection{Fatty acid analysis of beef, kidney fat and feeds}

The samples were thawed at $+4{ }^{\circ} \mathrm{C}$ one day before analysis. Total lipids were extracted from the meat, adipose tissue and feeds using the method of Bligh and Dyer [1], modified by Hallermayer [10]. Fatty acid methyl esters (FAME) were prepared using TMSH (Trimethyl- sulfonium hydroxide) for transesterification [23]. Beef, kidney fat and feed samples were analysed by gas-liquid chromatography. The gas chromatograph (HP, model 6890) was equipped with a flame ionisation detector and a capillary analytical column (DB 23; $60 \mathrm{~m} \times 0.25 \mathrm{~mm}$ i.d., $0.25 \mu \mathrm{m}$ film thickness consisting of 50\% cyanopropylmethylpolysiloxan, J\&W Scientific, CA). The oven temperature programme started at $160{ }^{\circ} \mathrm{C}$, the temperature was increased by a rate of $3.6^{\circ} \mathrm{C} \cdot \mathrm{min}^{-1}$ until reaching $230{ }^{\circ} \mathrm{C}$. The detector temperature was set at $250{ }^{\circ} \mathrm{C}$. Hydrogen was used as a carrier gas at a flow velocity of $40 \mathrm{~cm} \cdot \mathrm{s}^{-1}$. The injection volume was $1 \mu \mathrm{L}$ and the split ratio was set to $1: 100$. All fatty acids were identified using appropriate standards (SigmaAldrich, Deisenhofen, Germany, Restek, 
Table II. The effects of dietary energy treatments on the meat quality traits of the longissimus dorsi muscle.

\begin{tabular}{lcccc}
\hline & GSS $^{1}$ & MSW & MSC & SE \\
\hline No. & 17 & 26 & 27 & \\
$\mathrm{pH}_{48}$ & 5.64 & 5.60 & 5.61 & 0.09 \\
Colour ${ }^{2}: L$ & 37.3 & 38.2 & 37.9 & 2.9 \\
$\quad a^{*}$ & 15.9 & 16.3 & 16.4 & 2.8 \\
$\quad b^{*}$ & 5.0 & 5.6 & 5.7 & 1.9 \\
Ageing loss (\%) & 2.40 & 2.93 & 2.81 & 0.92 \\
Grilling loss (\%) & 29.7 & 31.7 & 31.5 & 3.09 \\
Grilling time (min) & $06: 44$ & $06: 64$ & $05: 93$ & 1.39 \\
Shear force $\left(\mathrm{kg} \cdot \mathrm{cm}^{-2}\right)$ & 4.1 & 4.2 & 3.9 & 1.1 \\
\hline
\end{tabular}

a, b Means within a row with different superscripts differ significantly $(P<0.05)$.

${ }^{1}$ GSS: Grass Silage and Sugar beet pulp + minerals; MSW: Maize Silage and Wheat + soyabean meal + minerals; MSC: Maize Silage and Corn + soyabean meal + minerals.

${ }^{2}$ Colour ( $L$, lightness; $a^{*}$, redness; $b^{*}$, yellowness).

Bad Homburg, Germany, Promochem, Wesel, Germany).

\subsection{Statistical analysis}

Collected data were statistically analysed according to the GLM procedure of SAS [22] in a one way design. The model included the dietary energy source (GSS, MSW or MSC). Differences among treatments were further analysed by the Duncan multiple range test.

\section{RESULTS}

\subsection{Meat quality and sensory evaluation}

Ultimate $\mathrm{pH}$, colour, ageing and grilling loss, grilling time and shear force values as objective measures of tenderness were not significantly affected by the dietary energy source (Tab. II). The average of the ultimate $\mathrm{pH}$ values was 5.62 with only minor variations. Differences in colour values (lightness: L; redness: $a^{*}$ and yellowness: $b^{*}$ ) did not reach significance among the three groups, but the grass silage group (GSS) showed slightly lower lightness (L) values and exhibited less saturation in colour (less redness and yellowness values) compared to the maize groups (MSW and MSC). A similar trend was noted in the ageing and grilling loss values; numerically the MSC group had lower values for the grilling time and shear force values (more tender) compared to the MSW and the GSS group.

Tenderness, juiciness and flavour evaluation by the panelists are presented in Table III. Non-significant differences were detected for tenderness and juiciness scores (subjective measure). Flavour evaluation showed that feeding the MSC diet significantly improved meat flavour compared to the GSS diet.

\subsection{Fatty acid profile of the experimental diets}

The results of the individual fatty acid composition of the GSS, MSW and MSC diets are shown in Table IV. In all diets, 
Table III. The effects of dietary treatments on sensory characteristics of the longissimus dorsi muscle.

\begin{tabular}{lcccc}
\hline & GSS $^{1}$ & MSW & MSC & SE \\
\hline No. & 11 & 17 & 18 & \\
Tenderness $^{2}$ & 3.45 & 3.41 & 3.14 & 0.87 \\
Juiciness $^{3}$ & 3.82 & 3.94 & 3.94 & 0.47 \\
Flavour $^{4}$ & $3.09^{\mathrm{b}}$ & $3.47^{\mathrm{ab}}$ & $3.61^{\mathrm{a}}$ & 0.6 \\
\hline
\end{tabular}

a, b Means within a row with different superscripts differ significantly $(P<0.05)$.

${ }^{1}$ GSS: Grass Silage and Sugar beet pulp + minerals; MSW: Maize Silage and Wheat + soyabean meal + minerals; MSC: Maize Silage and Corn + soyabean meal + minerals .

${ }^{2}$ Tenderness score from 1-6 $(1=$ tough and 6 = very tender).

3 Juiciness score from 1-6 (1 = dry and $6=$ juicy).

${ }^{4}$ Flavour score from $1-6(1=$ bad and $6=$ excellent).

the predominant saturated fatty acid (SFA) was $\mathrm{C} 16: 0$, the predominant monounsaturated fatty acid (MUFA) was C18:1-9c and the predominant polyunsaturated fatty acids (PUFA) were C18:2 and C18:3. But there were large differences between the individual diets, especially between the grass silage diet (GSS) and the two maize silage diets (MSW, MSC). The GSS diet contained a higher proportion of $\mathrm{C} 16: 0$ and C18:3 compared to the MSW and MSC diets, which contained a substantially higher proportion of C18:1 and C18:2. The GSS diet had a higher proportion of SFA and PUFA, whereas the MUFA proportion was higher in the MSW and MSC diets.

\subsection{Intramuscular fat content and fatty acid profile}

Significant differences were detected among the three groups in the intramuscular fat content and fatty acid profile of the LD muscle (Tab. V). Feeding the MSC diet significantly increased the intramuscular fat content compared to the MSW diet, but was not significantly different from the GSS diet. No significant differences were detected between the GSS and MSW groups.

Table IV. Fatty acid profile of the experimental diets.

\begin{tabular}{|c|c|c|c|}
\hline $\begin{array}{l}\text { Fatty acid } \\
\text { (\% composition FAME) }\end{array}$ & $\mathrm{GSS}^{1}$ & MSW & MSC \\
\hline C06:0 & 0.72 & 0.00 & 0.07 \\
\hline C10:0 & 0.18 & 0.00 & 0.00 \\
\hline $\mathrm{C} 11: 0$ & 0.25 & 0.79 & 1.12 \\
\hline C12:0 & 0.20 & 0.15 & 0.13 \\
\hline $\mathrm{C} 14: 0$ & 0.43 & 0.29 & 0.25 \\
\hline $\mathrm{C} 14: 1,9 \mathrm{c}$ & 0.09 & 0.00 & 0.00 \\
\hline C15:0 & 0.17 & 0.06 & 0.03 \\
\hline C16:0 & 16.53 & 14.15 & 13.36 \\
\hline $\mathrm{C} 16: 1,9 \mathrm{t}$ & 0.13 & 0.15 & 0.00 \\
\hline $\mathrm{C} 16: 1,9 \mathrm{c}$ & 1.22 & 0.30 & 0.38 \\
\hline $\mathrm{C} 17: 0$ & 0.29 & 0.18 & 0.18 \\
\hline C18:0 & 1.77 & 2.40 & 2.64 \\
\hline $\mathrm{C} 18: 1,9 \mathrm{t}$ & 0.14 & 0.00 & 0.00 \\
\hline $\mathrm{C} 18: 1,9 \mathrm{c}$ & 5.68 & 22.16 & 24.14 \\
\hline $\mathrm{C} 18: 1,11 \mathrm{t}$ & 0.70 & 0.75 & 0.80 \\
\hline $\mathrm{C} 18: 2,9 \mathrm{c}, 12 \mathrm{c}$ & 23.21 & 48.61 & 48.45 \\
\hline $\mathrm{C} 19: 1,9 \mathrm{c}$ & 0.25 & 0.17 & 0.15 \\
\hline $\mathrm{C} 18: 3,9 \mathrm{c}, 12 \mathrm{c}, 15 \mathrm{c}$ & 38.28 & 4.25 & 3.05 \\
\hline $\mathrm{C} 18: 2,9 \mathrm{c}, 11 \mathrm{c}$ & 0.48 & 0.87 & 0.87 \\
\hline C20:0 & 0.30 & 0.58 & 0.57 \\
\hline $\mathrm{C} 20: 1,11 \mathrm{c}$ & 2.70 & 0.38 & 0.46 \\
\hline $\mathrm{C} 20: 3,8 \mathrm{c}, 11 \mathrm{c}, 14 \mathrm{c}$ & 0.19 & 0.06 & 0.09 \\
\hline $\mathrm{C} 22: 0$ & 0.51 & 0.33 & 0.29 \\
\hline C23:0 & 0.18 & 0.12 & 0.11 \\
\hline $\mathrm{C} 24: 0$ & 0.55 & 0.48 & 0.44 \\
\hline SFA & 22.07 & 19.51 & 19.20 \\
\hline MUFA & 10.91 & 23.91 & 25.93 \\
\hline PUFA & 62.16 & 53.79 & 52.45 \\
\hline
\end{tabular}

${ }^{1}$ GSS: Grass Silage and Sugar beet pulp + minerals; MSW: Maize Silage and Wheat + soyabean meal + minerals; MSC: Maize Silage and Corn + soyabean meal + minerals. 
Table V. Effect of dietary treatments on the intramuscular fat content and fatty acid composition of the longissimus dorsi muscle.

\begin{tabular}{|c|c|c|c|c|}
\hline Fatty acid (\% composition, FAME) & $\mathrm{GSS}^{1}$ & MSW & MSC & SE \\
\hline Intramuscular fat (\%) & $1.78^{\mathrm{ab}}$ & $1.54^{\mathrm{b}}$ & $1.96^{\mathrm{a}}$ & 0.60 \\
\hline C7:0 & 0.07 & 0.08 & 0.07 & 0.03 \\
\hline C10:0 & 0.05 & 0.05 & 0.05 & 0.01 \\
\hline $\mathrm{C} 11: 0$ & 0.84 & 0.84 & 0.93 & 0.20 \\
\hline $\mathrm{C} 12: 0$ & 0.07 & 0.07 & 0.07 & 0.01 \\
\hline $\mathrm{C} 14: 0$ & 2.18 & 1.99 & 2.16 & 0.42 \\
\hline $\mathrm{C} 14: 1,9 \mathrm{c}$ & 0.29 & 0.32 & 0.37 & 0.14 \\
\hline $\mathrm{C} 15: 0$ & $0.49^{\mathrm{a}}$ & $0.33^{\mathrm{b}}$ & $0.30^{\mathrm{b}}$ & 0.07 \\
\hline $\mathrm{C} 16: 0$ & 23.94 & 23.08 & 23.74 & 1.90 \\
\hline $\mathrm{C} 16: 1,9 \mathrm{t}$ & $0.16^{\mathrm{a}}$ & $0.10^{\mathrm{b}}$ & $0.10^{\mathrm{b}}$ & 0.05 \\
\hline $\mathrm{C} 16: 1,9 \mathrm{c}$ & $2.33^{\mathrm{b}}$ & $2.42^{\mathrm{ab}}$ & $2.74^{\mathrm{a}}$ & 0.57 \\
\hline $\mathrm{C} 17: 0$ & $1.52^{\mathrm{a}}$ & $1.20^{\mathrm{b}}$ & $1.05^{\mathrm{c}}$ & 0.18 \\
\hline $\mathrm{C} 17: 1,10 \mathrm{c}$ & $0.56^{\mathrm{a}}$ & $0.53^{\mathrm{ab}}$ & $0.50^{\mathrm{b}}$ & 0.07 \\
\hline C18:0 & 16.74 & 16.01 & 15.80 & 1.57 \\
\hline $\mathrm{C} 18: 1,9 \mathrm{t}$ & $0.35^{\mathrm{b}}$ & $0.41^{\mathrm{ab}}$ & $0.45^{\mathrm{a}}$ & 0.12 \\
\hline $\mathrm{C} 18.1,11 \mathrm{t}$ & 1.86 & 1.47 & 1.80 & 0.84 \\
\hline $\mathrm{C} 18: 1,6 \mathrm{c}$ & $1.25^{\mathrm{a}}$ & $0.90^{\mathrm{b}}$ & $1.14^{\mathrm{a}}$ & 0.35 \\
\hline $\mathrm{C} 18: 1,9 \mathrm{c}$ & $29.53^{\mathrm{b}}$ & $31.77^{\mathrm{a}}$ & $33.03^{\mathrm{a}}$ & 2.83 \\
\hline $\mathrm{C} 18: 1,11 \mathrm{c}$ & $1.31^{\mathrm{c}}$ & $1.51^{\mathrm{a}}$ & $1.41^{\mathrm{b}}$ & 0.13 \\
\hline $\mathrm{C} 18: 2,9 \mathrm{t}, 12 \mathrm{t}$ & $0.34^{\mathrm{a}}$ & $0.22^{\mathrm{b}}$ & $0.20^{\mathrm{b}}$ & 0.16 \\
\hline $\mathrm{C} 18: 2,9 \mathrm{t}, 12 \mathrm{c}$ & 0.12 & 0.10 & 0.09 & 0.07 \\
\hline $\mathrm{C} 18: 2,9 \mathrm{c}, 12 \mathrm{c}$ & 6.40 & 7.70 & 6.41 & 2.26 \\
\hline $\mathrm{C} 18: 3,9 \mathrm{c}, 12 \mathrm{c}, 15 \mathrm{c}$ & $1.63^{\mathrm{a}}$ & $0.53^{\mathrm{b}}$ & $0.39^{\mathrm{b}}$ & 0.34 \\
\hline $\mathrm{C} 18: 2,9 \mathrm{c}, 11 \mathrm{t}$ (CLA) & 0.81 & 0.80 & 0.85 & 0.14 \\
\hline $\mathrm{C} 20: 0$ & $0.12^{\mathrm{a}}$ & $0.11^{\mathrm{b}}$ & $0.11^{\mathrm{b}}$ & 0.02 \\
\hline $\mathrm{C} 20: 1,11 \mathrm{c}$ & $0.19^{\mathrm{a}}$ & $0.16^{\mathrm{b}}$ & $0.16^{\mathrm{b}}$ & 0.03 \\
\hline $\mathrm{C} 20 \mathrm{a}, 11 \mathrm{c}, 14 \mathrm{c}$ & 0.14 & 0.14 & 0.12 & 0.07 \\
\hline $\mathrm{C} 20: 3,8 \mathrm{c}, 11 \mathrm{c}, 14 \mathrm{c}$ & $0.04^{\mathrm{b}}$ & $0.06^{\mathrm{a}}$ & $0.05^{\mathrm{ab}}$ & 0.03 \\
\hline $\mathrm{C} 21: 0$ & $0.38^{\mathrm{b}}$ & $0.49^{\mathrm{a}}$ & $0.37^{\mathrm{b}}$ & 0.16 \\
\hline $\mathrm{C} 20 \mathrm{a} 4,5 \mathrm{c}, 8 \mathrm{c}, 11 \mathrm{c}, 14 \mathrm{c}$ & $1.77^{\mathrm{ab}}$ & $2.14^{\mathrm{a}}$ & $1.64^{\mathrm{b}}$ & 0.69 \\
\hline $\mathrm{C} 20: 5,5 \mathrm{c}, 8 \mathrm{c}, 11 \mathrm{c}, 14 \mathrm{c}, 17 \mathrm{c}$ & $0.29^{\mathrm{a}}$ & $0.17^{\mathrm{b}}$ & $0.11^{\mathrm{c}}$ & 0.09 \\
\hline $\mathrm{C} 22: 4,7 \mathrm{c}, 10 \mathrm{c}, 13 \mathrm{c}, 16 \mathrm{c}$ & $0.23^{\mathrm{b}}$ & $0.30^{\mathrm{a}}$ & $0.25^{\mathrm{ab}}$ & 0.08 \\
\hline $\mathrm{C} 22: 5,7 \mathrm{c}, 10 \mathrm{c}, 13 \mathrm{c}, 16 \mathrm{c}, 19 \mathrm{c}$ & $0.72^{\mathrm{a}}$ & $0.58^{\mathrm{b}}$ & $0.39^{\mathrm{c}}$ & 0.22 \\
\hline SFA & $46.43^{\mathrm{a}}$ & $44.25^{\mathrm{b}}$ & $44.65^{\mathrm{b}}$ & 2.20 \\
\hline MUFA & $37.84^{\mathrm{b}}$ & $39.59^{b}$ & $41.69^{\mathrm{a}}$ & 3.27 \\
\hline PUFA & $12.51^{\mathrm{ab}}$ & $12.73^{\mathrm{a}}$ & $10.48^{\mathrm{b}}$ & 3.49 \\
\hline
\end{tabular}

${ }^{\mathrm{a}, \mathrm{b}, \mathrm{c}}$ Means within a row with different superscripts differ significantly $(P<0.05)$.

${ }^{1}$ GSS: Grass Silage and Sugar beet pulp + minerals; MSW: Maize Silage and Wheat + soyabean meal + minerals; MSC: Maize Silage and Corn + soyabean meal + minerals. 
The grass silage group (GSS) had a significantly higher content in saturated fatty acids than both maize silage groups. Also the major saturated fatty acids, palmitic (C16:0) and stearic (C18:0) acid, were not much affected by the dietary energy source. Relative to MSW, feeding the GSS diet resulted in a lower MUFA content. Oleic acid $(18: 1,9 \mathrm{c})$ contents were significantly increased by feeding starchy diets compared to the fibrous diet. Using the maize silage diet supplemented by wheat significantly increased the proportion of polyunsaturated fatty acids (PUFA) compared to the maize silage diet supplemented by corn. There were no significant differences between the grass silage diet and both maize silage diets.

No significant differences between the three groups were found for the linoleic acid $(\mathrm{C} 18: 2,9 \mathrm{c}-12 \mathrm{c})$ content, but linolenic acid (c18:3, 9c-12c-15c) was significantly higher in the grass silage group (GSS: $1.63 \%)$ compared to the maize silage groups (MSW: $0.53 \%$, and MSC: $0.39 \%$ ). Conjugated linoleic acid (CLA; C18:2, 9c11t) ranged from $0.80-0.85 \%$ across all diets, with no significant differences. The GSS group showed a significantly higher proportion of eicosapentaenoic acid (EPA; $\mathrm{C} 20: 5,5 c-8 c-11 c-14 c-17 c)$, as the most prominent omega-3 fatty acid, compared to the two maize silage based groups. Feeding the GSS diet significantly increased the n-3:n-6 ratio to 0.32 compared to the other two groups with values of 0.13 and 0.11 for MSW and MSC groups, respectively. No significant differences were detected between the MSW and MSC groups.

\subsection{Fatty acid composition of the kidney fat}

The fatty acid pattern of kidney fat is shown in Table VI and reveals similar trends to that noted for the intramuscular fat. The SFA and PUFA were significantly increased in the grass silage based feeding group compared to the two maize silage based feeding groups. Feeding the GSS diet significantly increased palmitic acid content but not stearic acid content compared to the MSW and MSC diets. In general, the stearic acid proportion was found to be much higher in the kidney fat (mean: $29.5 \%$ ) compared to the proportion in the LD muscle (mean: 16.2\%).

MUFA concentrations were significantly decreased by feeding the GSS diet compared to the MSW and MSC diets. Oleic acid (C18:1, 9c) proportions followed the same trend. Linoleic acid content was not affected by the dietary energy source while the GSS group had a significantly higher proportion of linolenic acids compared to MSW and MSC groups. The CLA proportion was found to be significantly higher in the GSS group compared to the MSW and MSC groups, in contrast to the intramuscular fat profile, where the differences were not significant.

\section{DISCUSSION}

In this trial, a typical high fibre diet was mixed from grass silage plus sugar beet pulp (GSS) having an NDF content of $48.1 \%$, whereas the contrasting high starch diets were composed of maize silage plus wheat (MSW, starch content 38.5\%) or maize silage plus corn (MSC, starch content $38.1 \%$ ). The supplementation of the maize silage based diet by wheat also created fast and high ruminal starch degradability, whereas the supplementation of the diet by corn created a rather low ruminal degradability of the starch [3]. There were almost no differences between the experimental groups in the measured meat quality criteria $(\mathrm{pH}$ and colour characteristics). The very stable $\mathrm{pH}$ values indicate that the ante mortem handling was appropriate. Furthermore, Priolo et al. [18] showed in an experiment with under-fed cattle that malnutrition can cause high ultimate $\mathrm{pH}$ values in beef, since animals 
Table VI. Effect of dietary treatments on the fatty acid composition of the kidney fat.

\begin{tabular}{|c|c|c|c|c|}
\hline Fatty acid (\% composition, FAME) & $\mathrm{GSS}^{1}$ & MSW & MSC & SE \\
\hline C10:0 & 0.06 & 0.06 & 0.06 & 0.01 \\
\hline C11:0 & 0.04 & 0.04 & 0.03 & 0.02 \\
\hline $\mathrm{C} 12: 0$ & 0.11 & 0.11 & 0.11 & 0.02 \\
\hline C13:0 & $0.03^{\mathrm{a}}$ & $0.02^{\mathrm{b}}$ & $0.02^{\mathrm{b}}$ & 0.01 \\
\hline $\mathrm{C} 14: 0$ & $3.17^{\mathrm{a}}$ & $2.86^{\mathrm{b}}$ & $3.00^{\mathrm{ab}}$ & 0.48 \\
\hline $\mathrm{C} 14: 19 \mathrm{c}$ & $0.14^{\mathrm{b}}$ & $0.20^{\mathrm{a}}$ & $0.21^{\mathrm{a}}$ & 0.09 \\
\hline $\mathrm{C} 15: 0$ & $0.89^{\mathrm{a}}$ & $0.52^{\mathrm{b}}$ & $0.46^{\mathrm{b}}$ & 0.13 \\
\hline $\mathrm{C} 16: 0$ & $25.68^{\mathrm{a}}$ & $23.75^{\mathrm{b}}$ & $23.94^{\mathrm{b}}$ & 2.52 \\
\hline $\mathrm{C} 16: 19 \mathrm{t}$ & $0.07^{\mathrm{a}}$ & $0.04^{\mathrm{b}}$ & $0.05^{\mathrm{b}}$ & 0.04 \\
\hline $\mathrm{C} 16: 19 \mathrm{c}$ & $1.23^{\mathrm{b}}$ & $1.53^{\mathrm{a}}$ & $1.52^{\mathrm{a}}$ & 0.33 \\
\hline $\mathrm{C} 17: 0$ & $2.43^{\mathrm{a}}$ & $1.88^{\mathrm{b}}$ & $1.67^{\mathrm{c}}$ & 0.23 \\
\hline $\mathrm{C} 17: 110 \mathrm{c}$ & 0.39 & 0.40 & 0.36 & 0.07 \\
\hline C18:0 & 30.29 & 29.27 & 28.83 & 3.37 \\
\hline $\mathrm{C} 18: 19 \mathrm{t}$ & $0.61^{\mathrm{b}}$ & $0.74^{\mathrm{a}}$ & $0.79^{\mathrm{a}}$ & 0.18 \\
\hline $\mathrm{C} 18: 111 \mathrm{t}$ & $4.09^{\mathrm{ab}}$ & $3.65^{\mathrm{b}}$ & $4.33^{\mathrm{a}}$ & 0.88 \\
\hline C18:1 c9 & $22.31^{\mathrm{b}}$ & $27.65^{\mathrm{a}}$ & $27.45^{\mathrm{a}}$ & 2.51 \\
\hline C18:1 c11 & $0.97^{\mathrm{b}}$ & $1.08^{\mathrm{a}}$ & $1.01^{\mathrm{b}}$ & 0.10 \\
\hline $\mathrm{C} 18: 29 \mathrm{t}, 12 \mathrm{t}$ & $0.59^{\mathrm{a}}$ & $0.35^{\mathrm{b}}$ & $0.34^{\mathrm{b}}$ & 0.07 \\
\hline $\mathrm{C} 18: 29 \mathrm{t}, 12 \mathrm{c}$ & 0.06 & 0.06 & 0.05 & 0.02 \\
\hline $\mathrm{C} 18: 29 \mathrm{c}, 12 \mathrm{t}$ & $0.07^{\mathrm{b}}$ & $0.09^{\mathrm{a}}$ & $0.09^{\mathrm{a}}$ & 0.01 \\
\hline $\mathrm{C} 18: 29 \mathrm{c}, 12 \mathrm{c}$ & 2.31 & 2.28 & 2.25 & 0.32 \\
\hline $\mathrm{C} 18: 39 \mathrm{c}, 12 \mathrm{c}, 15 \mathrm{c}$ & $0.66^{\mathrm{a}}$ & $0.23^{\mathrm{b}}$ & $0.21^{\mathrm{b}}$ & 0.10 \\
\hline C18:2 9c, 11t (CLA) & $0.54^{\mathrm{a}}$ & $0.41^{\mathrm{c}}$ & $0.47^{\mathrm{b}}$ & 0.09 \\
\hline $\mathrm{C} 20: 0$ & $0.31^{\mathrm{a}}$ & $0.27^{\mathrm{b}}$ & $0.25^{\mathrm{b}}$ & 0.05 \\
\hline $\mathrm{C} 20: 111 \mathrm{c}$ & 0.13 & 0.13 & 0.13 & 0.02 \\
\hline $\mathrm{C} 20: 211 \mathrm{c}, 14 \mathrm{c}$ & 0.03 & 0.02 & 0.02 & 0.01 \\
\hline $\mathrm{C} 20: 38 \mathrm{c}, 11 \mathrm{c}, 14 \mathrm{c}$ & $0.05^{\mathrm{a}}$ & $0.03^{\mathrm{b}}$ & $0.03^{b}$ & 0.01 \\
\hline $\mathrm{C} 21: 0$ & 0.02 & 0.03 & 0.02 & 0.01 \\
\hline $\mathrm{C} 20: 45 \mathrm{c}, 8 \mathrm{c}, 11 \mathrm{c}, 14 \mathrm{c}$ & $0.01^{\mathrm{b}}$ & $0.02^{\mathrm{b}}$ & $0.03^{\mathrm{a}}$ & 0.02 \\
\hline $\mathrm{C} 22: 0$ & $0.07^{\mathrm{a}}$ & $0.05^{\mathrm{b}}$ & $0.04^{\mathrm{b}}$ & 0.01 \\
\hline $\mathrm{C} 23: 0$ & $0.04^{\mathrm{a}}$ & $0.02^{\mathrm{b}}$ & $0.01^{\mathrm{b}}$ & 0.01 \\
\hline $\mathrm{C} 24: 0$ & 0.02 & 0.02 & 0.01 & 0.01 \\
\hline SFA & $63.15^{\mathrm{a}}$ & $58.88^{\mathrm{b}}$ & $58.45^{\mathrm{b}}$ & 2.88 \\
\hline MUFA & $29.95^{\mathrm{b}}$ & $35.40^{\mathrm{a}}$ & $35.85^{\mathrm{a}}$ & 2.82 \\
\hline PUFA & $4.31^{\mathrm{a}}$ & $3.51^{\mathrm{b}}$ & $3.49^{\mathrm{b}}$ & 0.46 \\
\hline
\end{tabular}

${ }^{\mathrm{a}, \mathrm{b}, \mathrm{c}}$ Means within a row with different superscripts differ significantly $(P<0.05)$.

${ }^{1}$ GSS: Grass Silage and Sugar beet pulp + minerals; MSW: Maize Silage and Wheat + soyabean meal + minerals; MSC: Maize Silage and Corn + soyabean meal + minerals. 
fed in this manner do not have the possibility to accumulate adequate glycogen reserves in their muscles. But ante mortem handling is of major importance for $\mathrm{pH}$ under practical conditions. Meat colour is a very important character when consumers are making their choice. In most cases meat colour is affected by the common action of different factors, including fattening regime, slaughter weight, age, genotype, and gender or ante mortem treatment; finally the best correlations will be found between meat colour and the ultimate $\mathrm{pH}$ and the intramuscular fat content. Direct effects of the diets on meat colour are considered rare and would be dependent on direct effects of the diet on the muscle myoglobin [18]. A fibre rich diet, as in the GSS group, provoked a higher hem pigment concentration, resulting in a darker meat compared to concentrate-fed Friesian bull calves (slaughter weights: 360 and $460 \mathrm{~kg}$, respectively) according to [24]. But these results were also associated with older animals. In the present study, steaks from animals fed fibre rich diets had numerically, but non-significantly lower L, a* and $b^{*}$ values. Also no significant differences in colour criteria were reported when crossbred steers from continental breeds were kept on pasture or were fed on a grass silage plus concentrate diet [8]. There were no differences in the results of the losses after ageing and grilling among the feeding groups. But the variation of these technological meat quality traits is often high, which is also reported by other studies $[7,20]$. In some publications, good correlations between the nutritional status of the animal and the shear force values are reported [12]. But an intensive feeding induces a lower age at slaughter, which can also affect this parameter $[14,20]$. In the present study no significant differences in shear force values were recorded among the feeding groups. However, the individual variation of the shear values was rather high.
Consumer evaluation of the eating quality is an important assessment of meat quality, of which the most important criteria are tenderness, juiciness and flavour. The sensory evaluation of meat tenderness is even less reproducible than the measurement of shear force values. In addition, this criterion strongly depends on post-mortem treatments such as cooling and ageing [12], other factors such as nutrition and selective breeding may additionally be used as in vivo strategies to optimise meat quality. The tenderness results showed similar values for the high fibre, grass silagefed group, and the maize silage plus wheat group, whereas the maize silage plus corn group was somewhat lower. The values for juiciness were similar across all 3 diets. But the flavour of the maize silage plus corn-fed group was significantly higher in comparison to the high fibre, grass silagefed group, whereas the other maize silage plus wheat-fed group were similar to the maize silage plus corn group. Although the maize silage plus corn group showed the highest intramuscular fat content, there was no relation between the fat content and flavour. This is not surprising, because the intramuscular fat content was low and varied only between 1.5 and $2.0 \%$ as discussed above. However, important differences in fatty acid composition of the intramuscular fat were noted. The MSC group has a significant different fatty acid pattern in comparison to the GSS group with lower PUFA and SFA and higher MUFA. There is good agreement with data from steers in feedlots with different feeding intensity [2]. In the US, Melton et al. [13] found that higher levels of C18:3 were related to less desirable beef flavour assessed using untrained assessors. However, this relation to different fatty acids needs further work. It may also be influenced by the fat content, the tocopherol content or by the "experience" of the taste panel.

The accumulation of fat in the muscle as intramuscular fat content is largely 
influenced by the energy content of the diet and the feeding regime [5]. Feeding maize silage supplemented by wheat (MSW) decreased the intramuscular fat content significantly to $1.54 \%$ compared to maize silage supplemented by corn with an average value of $1.96 \%$. This is an indication that corn-containing diets as a source of slow degradable starch increases the intramuscular fat concentration compared to diets supplemented by wheat as a source of rapid degradable starch. The high fibre diet (GSS) in this experiment also resulted in an intermediate intramuscular fat content, not significantly different from the two maize silage based diet groups. This result did not directly correspond with other studies $[5,20,24]$ because the energy content of the grass silage based diet (GSS) was $10 \%$ lower than the energy content of both maize silage based diets (MSW, MSC). This result, however, may also reflect the possibility, that a higher feed intake could equalise the energy intake. In addition, the present result was in agreement with other studies $[7,8]$ that did not find any special effects on the chemical composition of beef, when only the energy concentration of the diet was increased.

Meat is considered as a major source of fat in the human diet in industrial countries, especially the relatively high amount of saturated fatty acids in beef may have implications on the prevalence of obesity, cardiovascular diseases and cancer [26]. But lipids in beef may also provide some beneficial components such as PUFA or CLA. Therefore it is mandatory to consider not only the fat content in beef but also the concentration of individual lipid components. In the present study, the differences due to diets in the fatty acid pattern of the LD muscle are small but frequently significant. In general, the fibre rich, grass silage-fed group (GSS) showed a significant higher proportion of SFA, a slightly smaller proportion of MUFA, and about the same proportion of PUFA as the wheat supplemented maize silage group. The corn supplemented maize silage group had a significant lower PUFA proportion, but also the highest intramuscular fat content. The higher proportion of saturated fatty acids in the grass silage diet agrees well with other findings [15], showing an increase of SFA in the fatty acid pattern of pasture grazing cattle, especially in Simmental bulls with a generally lower intramuscular fat content. The MUFA content of the intramuscular fat can also be correlated with the overall carcass fatness in conjunction with high energy diet consumption $[11,20]$. This correlation may be responsible for the relatively high MUFA content found in the intramuscular fat of the MSC group. On the contrary, the reversible relation between the intramuscular fat content and the PUFA proportion could explain the lower PUFA proportion recorded for the MSC group. In general, an increasing energy level of the diet also increases the total MUFA content, while the total PUFA content decreases [5, 6, 21], however, the lower proportion of PUFA with increasing intramuscular fat content is a dilution effect of a relatively constant amount of phospholipids with an increasing amount of triacylglycerols. One possible reason is that an increase of the intramuscular fat content reduced the proportion of extractable phospholipids from the structural components of muscle cell membranes, which are basically rich in polyunsaturated fatty acids. The high percentages of n-3 fatty acids found in the intramuscular fat of the LD muscles of the GSS group resulted in an increased n-3/n-6 ratio in comparison with the MSW and MSC groups. This was in agreement with other findings and offers a positive aspect for human nutrition [9].

In ruminants, the fatty acid composition of the intramuscular or adipose tissues is less dependent on the diet as in monogastric animals [7]. A relatively high part of the fatty acids from the ruminant's 
diet are transformed or metabolised by microbial degradation in the rumen, including bio-hydrogenation of the PUFA [25]. In addition, de novo synthesis of fatty acids is well established in the rumen. Odd numbered, trans-configured or conjugated fatty acids may also occur in the pattern of the animal tissue, even when none of such fatty acids were present in the diet. But indirect effects may also occur. Hence the fibre rich group had a significantly higher proportion of C 15:0, C 16:1, 9t and C18:2, $9 \mathrm{t}, 12 \mathrm{t}$ fatty acids compared to the starch rich fed groups. Different pathways of hydrogeneration in ruminants may also contribute to minor changes in fatty acid relations [17]. Whereas the proportion of CLA (mainly C18:2, 9c, 11t) did not differ between the feeding groups, the linolenic acid percentage was in the GSS group at least 3 times higher than in both other groups (MSW, MSC). Grass as a basic feed also increased the linolenic acid concentration in other studies as compared to a maize silage based or concentrate rich diet [15]. So the variations of the fatty acid pattern of the intramuscular fat are at least partly a reflection of differences in the nutritional background $[7,15]$. C22:6n-3 was not detected in all samples. This finding is not unusual in beef and is confirmed by other works [4].

The kidney fat showed a much higher proportion of SFA, but confirmed in general the differences between feeding groups: SFA and PUFA proportions were significantly higher and the MUFA proportion significantly lower in the GSS group compared to the MSW and MSC groups. In the kidney fat, even a higher amount of CLA in the GSS group proved to be statistically significant.

\section{CONCLUSIONS}

The present data do not support the concept that basic meat quality characteristics can be manipulated by changing only the source of energy or the starch degradability. Steaks from animals fed a fibrous diet ad libitum were evaluated as good as steaks from starchy diets in terms of tenderness and juiciness. The steaks from the fibre fed group were ranked slightly but significantly lower compared to the starch fed groups but only for flavour. The fibrous diet resulted in an equivalent proportion of PUFA and CLA in the intramuscular fat, whereas the proportion of linolenic acid was at least three times higher. These results indicate that the diet may impact on the fatty acid pattern of the muscle or kidney fat. It may be concluded that feeding low priced fibrous diets such as grass silage plus sugar beet pulp ad libitum had no adverse effects on meat quality and eating attributes. In addition, the high fibre diet improved the fatty acid profile of muscle and adipose tissue by increasing CLA in the kidney fat, C18:3 fatty acid and PUFA contents compared to starch rich diets based on maize silage.

\section{REFERENCES}

[1] Bligh E.G., Dyer W.J., A rapid method of total lipid extraction and purification, Can. J. Biochem. Phys. 37 (1959) 911-917.

[2] Camfield P.K., Brown Jr. A.H., Lewis P.K., Rakes L.Y., Johnson Z.B., Effects of frame size and time-on-feed on carcass characteristics, sensory attributes, and fatty acid profiles of steers, J. Anim. Sci. 75 (1997) 1837-1844.

[3] Cerneau P., Michalet-Doreau B., In situ starch degradation of different feeds in the rumen, Reprod. Nutr. Dev. 31 (1991) 65-72.

[4] Dannenberger D., Nuernberg G., Scollan N., Schabbel W., Steinhart H., Ender K. Nuernberg K., Effect of diet on the deposition of n-3 fatty acids, conjugated linoleic and C18:1 trans fatty acid isomers in muscle lipids of German Holstein bulls, J. Agr. Food Chem. 52 (2004) 6607-6615.

[5] Di Luccia A., Satriani A., Barone C.M.A., Colatruglio P., Gigli S., Occidente M., Trivellone E., Zullo A., Matassino D., Effect of dietary energy content on the intramuscular fat depots and triglyceride composition 
of river buffalo meat, Meat Sci. 65 (2003) 1379-1389.

[6] Duckett S.K., Wagner D.G., Yates L.D., Dolezal H.G., May S.G., Effects of time on feed on beef nutrient composition, J. Anim. Sci. 71 (1993) 2079-2088.

[7] Fiems L.O., De Campeneere S., Cottyn B.G., Vanacker J.M., D'Heer B.G., Boucque Ch.V., Effect of amount and degradability of dietary starch on animal performance and meat quality of beef bulls, J. An. Physiol. Anim. Nutr. 82 (1999) 217-226.

[8] French P., O’Riordan E.G., Monahan F.J., Caffrey P.J., Vidal M., Mooney M.T., Troy D.J., Moloney A.P., Meat quality of steers finished on autumn grass, grass silage or concentrate-based diets, Meat Sci. 56 (2000) 173-180.

[9] French P., Stanton C., Lawless F., O'Riordan E.G., Monahan F.J., Caffrey P.J., Moloney A.P., Fatty acid composition, including conjugated linoleic acid, of intramuscular fat from steers offered grazed grass, grass silage, or concentrate-based diets, J. Anim. Sci. 78 (2000) 2849-2855.

[10] Hallermayer R., Eine Schnellmethode zur Bestimmung des Fettgehaltes in Lebensmitteln: I. Mitteilung: Die Bestimmung in Fleischwaren, Deutsche Lebensm.-Rundsch. 10 (1976) 356-359.

[11] Malau-Aduli A.E.O., Edriss M.A., Siebert B.D., Bottema C.D.K., Deland M.P.B., Pitchford W.S., Estimates of genetic parameters for triacylglycerol fatty acids in beef at weaning and slaughter, J. Anim. Physiol. Anim. Nutr. 83 (2000) 169-180.

[12] Maltin C., Balcerzak D., Tilley R., Delday M., Determinats of meat quality: tenderness, Proc. Nutr. Soc. 62 (2003) 337-347.

[13] Melton S.L., Amiri M., Davis G.W., Backus W.R., Flavor and chemical characteristics of ground beef from grass-forage-grain and grain-finished steers, J. Anim. Sci. 55 (1982) 77-87.

[14] Miller R.K., Cross H.R., Crouse J.D., Tatum J.D., The influence of diet and time on feed on carcass traits and quality, Meat Sci. 19 (1987) 303-313.

[15] Nuernberg K., Nuernberg G., Ender K., Lorenz S., Winkler K., Rickert R., Steinhart $\mathrm{H}$., $N-3$ fatty acids and conjugated linoleic acids of longissimus muscle in beef cattle, Eur. J. Lipid Sci. Tech. 104 (2002) 463-471.
[16] Ørskov E.R., Starch digestion and utilization in ruminants, J. Anim. Sci. 63 (1986) 1624 1633.

[17] Piperova L.S., Sampugna J., Teter B.B., Kalscheur K.F., Yurawecz M.P., Ku Y., Morehouse K.M., Erdman R.A., Duodenal and milk trans octadecenoic acid and conjugated linoleic acid (CLA) isomers indicate that postabsorptive synthesis is the predominant source of cis-9-containing CLA in lactating dairy cows, J. Nutr. 132 (2002) 12351241.

[18] Priolo A., Micol D., Agabriel J., Effects of grass feeding systems on ruminant meat colour and flavour. A review, Anim. Res. 50 (2001) 185-200.

[19] Reynolds C.K., Sutton J.D., Beever D.E., Effects of feeding starch to dairy cattle on nutrient availability and production, in: Garnsworthy P.C., Wiseman J. (Eds.), Recent developments in ruminant nutrition 4, Nottingham University Press, Nottingham, UK, 2002, pp. 163-190.

[20] Sami A.S., Augustini C., Schwarz F.J., Effects of feeding intensity and time on feed on performance, carcass characteristics and meat quality of Simmental bulls, Meat Sci. 67 (2004) 195-201.

[21] Sami A.S., Augustini C., Schwarz F.J., Effect of feeding intensity and time on feed on intramuscular fatty acid composition of Simmental bulls, J. Anim. Physiol. Anim. Nutr. 88 (2004) 179-187.

[22] SAS, Release 6.12. SAS institute Inc., Cary North Carolina, USA, 1996.

[23] TMSH-Methode, DGF-Einheitmethoden CVI, 11e, 1998.

[24] Vestergaard M., Oksbjerg N., Henckel P., Influence of feeding intensity, grazing and finishing feeding on muscle fibre characteristics and meat colour of semitendinosus, longissimus dorsi and supraspinatus muscles of young bulls, Meat Sci. 54 (2000) 177185.

[25] Wood J.D., Enser M., Factors influencing fatty acids in meat and the role of antioxidants in improving meat quality, Brit. J. Nutr. 78 (Suppl. 1) (1997) S49-S60.

[26] Wood J.D., Richardson R.I., Nute G.R., Fisher A.V., Campo M.M., Kasapidou E., Sheard P.R., Enser M., Effects of fatty acids on meat quality: a review, Meat Sci. 66 (2003) 21-32. 